\title{
Determination of Aspartame Levels in Soft Drinks Consumed in
} Ankara, Turkey

\author{
Elif Çelik ${ }^{1}$, Buket Er Demirhan ${ }^{1}$, Burak Demirhan ${ }^{1} \&$ Gülderen Yentür ${ }^{1}$ \\ ${ }^{1}$ Department of Food Analysis, Faculty of Pharmacy, Gazi University, 06330, Ankara, Turkey \\ Correspondence: Gülderen Yentür, Department of Food Analysis, Faculty of Pharmacy, Gazi University, 06330, \\ Ankara, Turkey. Tel: 90-312-202-3200. E-mail: yentur@gazi.edu.tr
}

Received: June 11, 2014 Accepted: August 4, 2014 Online Published: September 16, 2014

doi:10.5539/jfr.v3n6p156 URL: http://dx.doi.org/10.5539/jfr.v3n6p156

\begin{abstract}
Aspartame is commonly used as artificial sweeteners in several food products. Excess amounts of aspartame can be harmful to human health. Therefore, the investigation of aspartame levels in foods is important. The aim of this study was to determine levels of aspartame in soft drinks and to evaluate whether these amounts were within the Turkish Food Codex values or not. For this purpose, total number of 90 soft drink samples (A, B, C, D, E and F brands) including 15 from each brand were collected from supermarkets in Ankara province, Turkey . In this study, spectrophotometric method was used for the quantitative determination of aspartame in the samples. Mean levels ( \pm S.E) of aspartame in samples of A, B, C, D, E and F brands were found as $156.81 \pm 7.29 \mathrm{mg} / \mathrm{L}$, $208.67 \pm 8.97 \mathrm{mg} / \mathrm{L}, 236.58 \pm 17.91 \mathrm{mg} / \mathrm{L}, 299.54 \pm 26.19 \mathrm{mg} / \mathrm{L}, 202.39 \pm 8.08 \mathrm{mg} / \mathrm{L}$ and $223.28 \pm 14.08 \mathrm{mg} / \mathrm{L}$, respectively. Our data revealed that mean levels of aspartame were found within Turkish Food Codex in all samples. However, some samples were not found appropriate according to the label information.
\end{abstract}

Keywords: aspartame, food additives, spectrophotometric method

\section{Introduction}

Soft drink industry has the largest scale in the world. Additionally, the additives of beverages such as sweeteners must be contained in the labels (Grembecka, Baran, Blazewicz, Fijalek, \& Szefer, 2014). Artificial sweeteners used as sugar substitutes are important to control the calorie intake in obesity and metabolic diseases such as diabetes and hyperglycaemia (Zygler, Wasik, \& Namiesnik, 2009; Serdar \& Knežević, 2011). Aspartame (ASP), 1-methyl N-L-a-aspartyl-L-phenylalanine, is an artificial sweetener consisting aspartic acid, phenylalanine and methanol (Ashok, Sheeladevi, \& Wankhar, 2013a; Choudhary \& Rathinasamy, 2014). It is a white crystalline powder and it is about 200 times as sweet as sucrose (Mazurek \& Szostak, 2011). ASP is widely used in food products including beverages, yoghurts, breakfast cereals and confectionary products, and pharmaceutical industries (Ashok et al., 2013a; Choudhary \& Rathinasamy, 2014; Mazurek \& Szostak, 2011; Kashanian, Khodaei, \& Kheirdoosh, 2013). Orally ingested ASP is rapidly metabolized to aspartic acid, phenylalanine and methanol (Kashanian et al., 2013; Ashok, Sheeladevi, \& Wankhar, 2014; Choudhary \& Rathinasamy, 2014). Chronic exposure of ASP resulted in headache, blurred vision, epileptic tits and brain tumors, eye problems, numbness, insomnia, memory loss, nausea, slurred speech, loss of energy, hyperactivity, hearing problems, neurological and behavioral disturbances (Ashok, Wankhar, Sheeladevi, \& Wankhar, 2013b).

Most conducted studies on ASP are associated with the mechanism of toxicity and cancer (Ashok et al., 2013b). It was reported that ASP is a multipotential carcinogenic agent, even at a daily dose of $20 \mathrm{mg} / \mathrm{kg}$ body weight (Soffritti, Belpoggi, Esposti, Lambertini, Tibaldi, \& Rigano, 2006). Aspartic acid and phenylalanine might cross the blood brain-barrier and causes memory loss due to deterioration in the neurons of the brain (Mehl-Madrona, 2008). Increase in the levels of plasma phenylalanine and aspartic acid after ingestion of ASP causing accumulation of phenylalanine and its derivatives in the blood, tissues and urine, known as phenylketonuria, is caused by lack of phenylalanine hydroxylase enzyme (Humphries, Pretorius, \& Naude, 2008). Methanol, metabolic derivative of ASP, is converted to formate in the body. This formate is excreted or it can be give rise to formaldehyde, diketopiperazine and other toxic derivatives (Clarke, 2000).

Joint FAO/WHO Expert Committee on Food Additives (JECFA), the EU Scientific Committee for Food (SCF) and the European Food Safety Authority (EFSA) have evaluated and established an acceptable daily intake (ADI) for ASP as $40 \mathrm{mg} / \mathrm{kg}$ body weight/day (European Food Safety Authority [EFSA], 2013). In the Turkish Food 
Codex (TFC), ASP is regulated with maximum levels as $600 \mathrm{mg} / \mathrm{kg}$ or $\mathrm{mg} / \mathrm{L}$ in different foodstuffs (TFC, 2006; TFC, 2013).

The aim of this study was to determine the ASP amounts in soft drink samples collected from supermarkets of Ankara province and to evaluate whether ASP amounts were within the TFC values.

\section{Materials and Method}

\subsection{Sample Collection}

In this study, total of 90 diet gassy and non-gassy soft drink samples of six brands (A, B, C, D, E, and F) were collected from supermarkets located in Ankara province, Turkey. The samples with different serial numbers were used in the analysis. Samples stored under the room temperature and opened before for analysis.

\subsection{Analysis of Aspartame}

The extraction and determination procedure for analysis of samples were based on the method described by Lau et al. (1988).

One and a half milliliters of a sample and $0.5 \mathrm{~mL}$ acetate buffer (pH: 3.5) were transferred to a centrifuge tube. Then, $10 \mathrm{~mL}$ propylene carbonate was added and mixed for $5 \mathrm{~min}$ in an ultrasonic bath and centrifuged for $5 \mathrm{~min}$ Seven $\mathrm{mL}$ of lower phase was dried with anhydrous sodium sulfate. Two $\mathrm{mL} 4 \%$ ninhydrin solution was added to the $3 \mathrm{~mL}$ of the dried solution and the solution was boiled in a boiling water bath for $20 \mathrm{~min}$. Then, the solution was cooled and diluted with ethyl alcohol to a total of $10 \mathrm{~mL}$. The absorbance of diluted solution was measured at $585 \mathrm{~nm}$ wavelength by spectrophotometer (Beckman DU650). Standards of ASP were measured with the same process. The calibration curve was constructed by using a series of dilutions containing different levels $(3.7-30 \mu \mathrm{g} / \mathrm{mL})$ of ASP. The analysis was conducted in duplicate for each sample. All reagents were of analytical grade.

\subsection{Statistical Analysis}

The results were evaluated according to One Way ANOVA and for comparison of the aspartame levels and TFC values One-Sample $\mathrm{t}$ test was used. Student $\mathrm{t}$ test was conducted for statistical comparisons between brands (Daniel, 1991).

\section{Results}

The concerning values are shown in Table 1. The results of the analysis were evaluated within the TFC values $(600 \mathrm{mg} / \mathrm{L})$. The mean ASP levels ( \pm S.E) of A, B, C, D, E and F brands were found as $156.81 \pm 7.29 \mathrm{mg} / \mathrm{L}$, $208.67 \pm 8.97 \mathrm{mg} / \mathrm{L}, 236.58 \pm 17.91 \mathrm{mg} / \mathrm{L}, 299.54 \pm 26.19 \mathrm{mg} / \mathrm{L}, 202.39 \pm 8.08 \mathrm{mg} / \mathrm{L}$ and $223.28 \pm 14.08 \mathrm{mg} / \mathrm{L}$, respectively. The difference between the mean levels of ASP in samples of brands (A, B, C, D, E, F) and TFC values $(600 \mathrm{mg} / \mathrm{L})$ were statistically significant $(\mathrm{p}<0.001)$. Also, the difference between the mean levels of two different brands $(A$ and $B)$ of the same firm were statistically significant $(p<0.001)$. However, the difference between the mean levels of two different brands (C and D) of the same firm were statistically insignificant $(\mathrm{p}>0.05)$.

Table 1. Statistical analysis for levels of aspartame $(\mathrm{mg} / \mathrm{L})$ in soft drink samples

\begin{tabular}{lllll}
\hline Brands & N & X \pm S.E & Min. & Max. \\
\hline A & 15 & $156.81 \pm 7.29^{*}$ & 102.03 & 205.04 \\
B & 15 & $208.67 \pm 8.97^{*}$ & 155.99 & 273.27 \\
C & 15 & $236.58 \pm 17.91^{*}$ & 149.74 & 370.48 \\
D & 15 & $299.54 \pm 26.19^{*}$ & 180.51 & 457.43 \\
E & 15 & $202.39 \pm 8.08^{*}$ & 143.95 & 246.06 \\
F & 15 & $223.28 \pm 14.08^{*}$ & 156.88 & 303.59 \\
\hline
\end{tabular}

*: $\mathrm{p}<0.001$ (the difference between the mean level of aspartame in samples and the TFC values; $600 \mathrm{mg} / \mathrm{L}$ ).

Our data revealed that the ASP levels found in all of the samples were within the TFC values. However, in some samples more ASP addition than specified label information was determined. 


\section{Discussion}

Limited research has been conducted on the determination of ASP levels in soft drinks in Turkey. Bayhan et al. (1997) found mean ASP levels in soft drink samples as $560.16 \pm 8.53 \mathrm{mg} / \mathrm{L}, 519.85 \pm 13.73 \mathrm{mg} / \mathrm{L}, 261.85 \pm 6.04$ $\mathrm{mg} / \mathrm{L}$ and $219.97 \pm 7.07 \mathrm{mg} / \mathrm{L}$, respectively. These results were found to be higher in comparison with present study.

Also, limited researches related to the ASP analysis in the beverages have been seen in different countries. Pesek and Matyska (1997) determined mean level of ASP in diet cola A, diet cola B, diet ginger ale and diet iced tea samples as $507 \mathrm{mg} / \mathrm{L}, 426 \mathrm{mg} / \mathrm{L}, 207 \mathrm{mg} / \mathrm{L}$ and $143 \mathrm{mg} / \mathrm{L}$, respectively in USA. Zhu et al. (2005) reported ASP levels ranged between $317.20 \mathrm{mg} / \mathrm{L}$ and $7234.66 \mathrm{mg} / \mathrm{L}$ in soft drink samples in China. Hajjaj et al. (2012) tested ASP of three different cola brands in Denmark and reported the ASP levels ranged between $162.02 \mathrm{mg} / \mathrm{L}$ and $589.99 \mathrm{mg} / \mathrm{L}$. Alghamdi et al. (2005) analyzed 29 different beverage samples for ASP in Riyadh, and found that the mean ASP level as $246.7 \mathrm{mg} / \mathrm{L}$ in beverage samples. Lino et al. (2008) studied 48 drink samples (25 soft drinks, 13 soft drinks based on mineral water, 10 nectar) in Portugal for ASP and found ASP level as $89 \mathrm{mg} / \mathrm{L}, 82$ $\mathrm{mg} / \mathrm{L}$ and $73 \mathrm{mg} / \mathrm{L}$ in soft drinks, soft drinks based on mineral water, nectar, respectively. Serdar and Knežević (2011) analyzed 41 soft drinks from plant extract, 11 fruit juices and 26 artificially and flavored drinks in Croatia They reported ASP levels within a range between 153.69 to $876.42 \mathrm{mg} / \mathrm{L}, 80.29$ to $435.05 \mathrm{mg} / \mathrm{L}$ and 198.22 to $709.36 \mathrm{mg} / \mathrm{L}$ in soft drinks from plant extract, fruit juices and artificially and flavored drinks, respectively. Bergamo et al. (2011) determined mean ASP levels of soft drink as $94 \pm 5 \mathrm{mg} / \mathrm{L}$ in Brazil. Variability in the ASP levels observed in these researches may be due to be determined in the different countries. This may be related to the differences in the production technologies.

Surveillance and monitoring of food additives is important in terms of public health and food safety. For this purpose, allowed ASP levels in different foods are controlled by the legal regulations. As a result, ASP levels of all soft drinks samples were found within TFC value $(600 \mathrm{mg} / \mathrm{L})$. ASP levels of non-alcoholic beverages were within TFC values, but some samples contained different ASP levels in contradistinction to the sample labels was determined. Consequently, ASP levels in foods must be kept under the control in order to protect the health of the consumer.

\section{References}

Alghamdi, A. H., Alghamdi, A. F., \& Alwarthan, A. A. (2005). Determination of Content Levels of Some Food Additives in Beverages Consumed in Riyadh City. J King Saud Univ, 18(2), 99-109.

Ashok, I., Sheeladevi, R., \& Wankhar, D. (2013a). Long term effect of aspartame (Artificial sweetener) on membrane homeostatic imbalance and histopathology in the rat brain. Free Radicals and Antioxidants, 3, S42-49. http://dx.doi.org/10.1016/j.fra.2013.09.003

Ashok, I., Sheeladevi, R., \& Wankhar, D. (2014). Effect of long-term aspartame (artificial sweetener) on anxiety, locomotoractivity and emotionality behavior in Wistar Albino rats. Biomed Prev Nutr, 4, 39-43. http://dx.doi.org/10.1016/j.bionut.2013.04.002

Ashok, I., Wankhar, D., Sheeladevi, R., \& Wankhar, W. (2013b). Long-term effect of aspartame on the liver antioxidant status andhistopathology in Wistar albino rats. Biomed Prev Nutr, 4, 299-305. http://dx.doi.org/10.1016/j.bionut.2013.10.002

Bayhan, A., Küçükkömürler, S., \& Yentür, G. (1997). Bazı Gıda Maddelerine Katılan Yapay Tatlandırıcılar Üzerinde Araştırmalar. Glda, 22(3), 187-191 (In Turkish).

Bergamo, A. B., Silva, J. A. F., \& Jesus, D. P. (2011). Simultaneous determination of aspartame, cyclamate, saccharin and acesulfame-K in soft drinks and tabletop sweetener formulations by capillary electrophoresis with capacitively coupled contactless conductivity detection. Food Chem, 124, 1714-1717. 10.1016/j.foodchem.2010.07.107

Choudhary, A. K., \& Rathinasamy, S. D. (2014). Aspartame induces alteration in electrolytes homeostasis of immuneorgans in wistar albino rats. Biomed Prev Nutr, 4, 181-187. http://dx.doi.org/10.1016/j.bionut.2013.12.006

Clarke, J. (2000). Aspartame Concerns. An overview for health professionals. An Additive Survivors'Network (UK) Publication. Scottish Coordinator Additives Survivors' Network 35 Hamilton Drive Glasgow.

Daniel, N. W. (1991). Bioistatistic: A foundation for analysis in the health sciences (5 th ed). New York: Wiley.

EFSA. (2013). Scientific Opinion on the re-evaluation of aspartame (E 951) as a food Additive. EFSA Journal, 11(12), 3496, p. 1-263. 
Grembecka, M., Baran, P., Blazewicz, A., Fijalek, Z., \& Szefer, P. (2014). Simultaneous determination of aspartame, acesulfame-K,saccharin, citric acid and sodium benzoate in various food products using HPLC-CAD-UV/DAD. Eur Food Res Technol, 238, 357-365. http://dx.doi.org/10.1007/s00217-013-2111-x

Hajjaj, M. A., Poulsen, M. G., Nielsen, M. H. L., \& Dominguez, J. V. (2012). Determination of Aspartame in Soft Drinks Using HPLC. University of Southern Denmark.

Humphries, P., Pretorius, E., \& Naude, H. (2008). Direct and indirect cellular effects of aspartame on the brain. Eur J Clin Nutr, 62, 451-462. http://dx.doi.org/10.1038/sj.ejen.1602866

Kashanian, S., Khodaei, M. M., \& Kheirdoosh, F. (2013). In vitro DNA binding studies of Aspartame, an $\begin{array}{llllll}\text { artificial sweetener. } J \text { Photochem Photobiol } & B, & 120, & 104-110 .\end{array}$ http://dx.doi.org/10.1016/j.jphotobiol.2013.01.001

Lau, O. W., Luk, S. F., \& Chan, W. M. (1988). Spectrophotometric Determination of Aspartame in Soft Drinks with Ninhydrin as Reagent. Analyst, 113, 765-768. http://dx.doi.org/10.1039/an9881300765

Lino, C. M., Costa, I. M., Pena, A., Ferreira, R., \& Cardoso, S. M. (2008). Estimated intake of the sweeteners, acesulfame-K and aspartame, from soft drinks, soft drinks based on mineral waters and nectars for a group of Portuguese teenage students. Food Addit Contam, 25(11), 1291-1296. http://dx.doi.org/10.1080/02652030802195309

Mazurek, S., \& Szostak, R. (2011). Quantification of aspartame in commercial sweeteners by FT-Raman spectroscopy. Food Chem, 125, 1051-1057. http://dx.doi.org/10.1016/j.foodchem.2010.09.075

Mehl-Madrona, L. (2008). Autism an overview and theories on its causes. Retrieved from http://www.healing-arts.org/children/autism-overview.htm

Pesek, J. J., \& Matyska, M. T. (1997). Determination of aspartame by high-performance capillary electrophoresis. J Chromatogr A, 781, 423-428. http://dx.doi.org/10.1016/S0021-9673(97)00289-6

Serdar, M., \& Knežević, Z. (2011). Determination of Artificial Sweeteners in Beverages and Special Nutritional Products Using High Performance Liquid Chromatography. Arh Hig Rada Toksikol, 62, 169-173. http://dx.doi.org/10.2478/10004-1254-62-2011-2084

Soffritti, M., Belpoggi, F., Esposti, D. D., Lambertini, L., Tibaldi, E., \& Rigano, A. (2006). First Experimental Demonstration of the Multipotential Carcinogenic Effects of Aspartame Administered in the Feed to Sprague-Dawley Rats. Environ Health Persp, 114(3), 379-385. http://dx.doi.org/10.1289/ehp.8711

TFC. Turkish Food Codex. (2006). Glda Maddelerinde Kullanılan Tatlandirıcllar Tebliği 2006/45. Retrieved from http://www.resmigazete.gov.tr/eskiler/2006/09/20060921-10.htm (In Turkish)

TFC. Turkish Food Codex. (2013). Glda Katkl Maddeleri Yönetmeliği. Retrieved from http://www.resmigazete.gov.tr/eskiler/2013/06/20130630-4.htm (In Turkish)

Zhu, Y., Guo, Y., Ye, M., \& James, F. S. (2005). Separation and simultaneous determination of four artificial sweeteners in food and beverages by ion chromatography. $J$ Chromatogr A, 1085, 143-146. http://dx.doi.org/10.1016/j.chroma.2004.12.042

Zygler, A., Wasik, A., \& Namiesnik, J. (2009). Analytical methodologies for determination of artificial sweeteners in foodstuffs. Trend Anal Chem, 28(9), 1082-1102. http://dx.doi.org/10.1016/j.trac.2009.06.008

\section{Copyrights}

Copyright for this article is retained by the author(s), with first publication rights granted to the journal.

This is an open-access article distributed under the terms and conditions of the Creative Commons Attribution license (http://creativecommons.org/licenses/by/3.0/). 